pests of sugar-cane. Colonies of Tiphia were successfully established in several places, and the wasps began to spread, doing very useful work in the control of Phytalus. The beneficial effect of wasps was soon appreciated by sugar planters, who became very eager to secure the parasites for their own plantations. As a result, mass capture of the wasp and even a regular trade in them developed to such an extent that the carefully elaborated plans for a gradual establishment and spread of the parasite were in danger of being overthrown. In order to prevent this an ordinance has just been issued by the Government of Mauritius providing for the protection of any insect declared to be beneficial, and forbidding anyone to kill, injure, or molest any such insect. The declaration of an insect as beneficial rests with the Director of Agriculture, who is empowered to make surveys of private lands in order to ascertain the presence and the quantity of beneficial insects available for capture and distribution. The ordinance can be regarded as a de jure recognition of biological control of insect pests.

\section{Federal Council for Chemistry}

IN the report for 1931 of the Federal Council for Chemistry, the objects and constitution of the Council are defined with greater precision than heretofore. The objects are: to foster and advance the scientific interests of chemistry in all its branches, and to that end (1) to represent the views of British chemists both nationally and internationally, (2) to cooperate with those bodies in Great Britain and the British Empire representing the science of chemistry and to co-ordinate their scientific activity, (3) to enter into scientific relations and co-operate with similar bodies in other countries, and, in particular, to act as the representative of the British associations of chemistry in the International Union of Chemistry. The report states that a sum of $£ 1642$ was collected as the contribution of chemists and the chemical industries towards one-fifth of the estimated cost of the Faraday Exhibition in 1931. The committee appointed to consider the question of forming a British chemical standardising body having reported in favour of participation in the new British Standards Institution, unanimous approval of this course has been expressed by the Council. After consideration of the report of the Bureau of Chemical Abstracts on the memorandum submitted by Sir Frederic Nathan advocating the establishment of an international system for abstracting and indexing chemical literature, the Council has reaffirmed its previous decision that the system at present in use in England is satisfactory. Under the heading of international affairs it is announced that the ninth International Congress of Pure and Applied Chemistry and the eleventh Conference of the International Union of Chemistry, which were to have been held in Madrid in April 1932, have been postponed to a more favourable time. The report of the discussion on the chemistry of the carbohydrates held at Liège in 1930 has been issued in separate form, and can be obtained from the Société de Chimie Industrielle (50 fr.). During the year 1931
Russia was admitted an adherent organisation of the International Union of Chemistry.

\section{Tropical Medicine and Hygiene}

The Prince of Wales opened Manson House, the new headquarters in Portland Place, London, W., of the Royal Society of Tropical Medicine and Hygiene, on March 17. The premises will perpetuate the memory of Sir Patrick Manson, a pioneer in the science of tropical medicine. His Royal Highness pointed out that one of the great obstacles to the development of tropical countries is not so much the climatic conditions but the diseases which are prevalent in them. In spite of this, however, great progress has been made in the study of tropical diseases during the last thirty years. This progress has been due chiefly to the pioneer investigators who devoted their lives to the study of tropical diseases and medicine on the spot, thus saving the lives of hundreds of thousands of the inhabitants of the tropics, not only European but also the native population. One serious consideration at present is the increase in facilities for the spread of disease brought about by the improvement in communications. This problem must be attacked by the investigation of collected pathological material and the establishment of centralised research to help other centres in the invostigation and control of disease. In Manson House, discoveries, experiences, and opinions of workers in tropical lands can be pooled for the help of those who will have to face similar problems in the future.

\section{Climate and Soil Physics}

Dr. B. A. KEEN, assistant director of the Rothamsted Experimental Station, delivered the G. J. Symons memorial lecture before the Royal Metcorological Society on March 16, his subject being "Soil Physics in Relation to Meteorology". Dr. Keen introduced his subject with a description of the different soil types found in different climatic zones. In soil temperatures, the porous and moist nature of soil produces special effects. In particular, the downward percolation of water appreciably reduces the loss of heat from the soil. A full account was given of recent investigations at Rothamsted on the movement and distribution of water in the soil. It was shown that such movements are much less, both in amount and extent, than previously supposed. Water which has reached a depth of about six feet in the average soil is not drawn back to the surface again by evaporation. Many of the farmers' and gardeners' cultivation operations were at one time supposed to conserve this subsoil water for use by plants, but the explanation has now to be sought for in other directions. The lecture concluded with a review of the development of cultivation implements, from the rudimentary form of a pointed stick, which merely stirred the ground, to the wide range of different types now in use.

\section{The Talkatome Home 'Talkie' Equipment}

Hоме film projectors were popular a few years ago; but apparently silent films are becoining out of date: A demonstration was given by the British Talkatome, Ltd., at their offices at Wells Street, Jermyn 
Street, London, S.W.I, on March 16, of a sound apparatus for home use. The device consists of a synchronised turntable attached to the projector by a flexible drive. A special sound disc is used in conjunction with the film, and this is placed on the turntable. An electrical pick-up carries the gramophone needle, which is connected to a loud speaker either by the user's radio set or alternatively by a special amplifier. The makers have prepared a library of films, including comedies and travel and educational films. The device shown worked quite satisfactorily, and the operation of the equipment is simple. In some cases it might be useful in colleges and schools. The turntable is listed at twenty-five guineas, and the hire of a film from the library is $10 s$.

\section{Witchcraft on the Gold Coast}

The Christian Council of the Gold Coast, a body consisting of representatives of all denominations, of which the Anglican Bishop of Accra is chairman, has taken the unusual course-not, however, without precedent in spiritistic circles-of issuing a challenge to witchcraft. The Council has published a notice in the local press that it is prepared to pay the sum of $£ 10$ to any person who, within the term of six months from date, will either 'eat' a papaw, or some other fruit selected by the Committee, at a distance of five yards, without coming into physical contact with it; or extract from a sealed box, without breaking the seal, an article deposited in it by the Committee; or transform himself into any beast, bird, or creeping thing. All these operations are among the powers attributed to the local witches. The Council, in making this challenge, is careful to point out that while many innocent persons are put in great terror by their fear of witcheraft, the harm from it is due not to the powers of witchcraft, but to their fear. Even with this proviso, however, the Council would appear to have been unsuccessful in its attempt to avoid criticism. Objection has been taken to its action on the ground that it constitutes 'witch-finding', and as such is contrary to a local ordinance.

ExTRacts from the local press criticising the Council are quoted in an article describing the situation at Accra, which appeared in the Manchester Guardian of March 15. The Council is recommended to abstain from meddling with witchcraft; and as it does not affirm or deny the belief, it is advised "to leave the Devil alone". Apparently the Council takes its stand on precedent ; for it recalls that in the last hundred years the power of 'fetish priests' has been broken in this manner on many occasions. The action of the Council is directed against 'witch-finders' as well as the witch. Some idea of the conditions with which the churches have to deal may be gained from a case quoted from the Vox Populi, a local journal, of Feb. 20, which reports the 'finding' of a witch, who was. charged with killing the child of a sister. When the dead child was placed on her lap, a snake fell from her body. This was taken as proof positive of her guilt, and the woman had to be conveyed away secretly to save her from popular vengeance.

\section{Prehistoric Society of East Anglia}

AT the annual meeting of the Prehistoric Society of East Anglia, held at Norwich on Feb. 29, Mr. J. Reid Moir was elected president. In a paper on the evolution of the rostrocarinate and hand-axe in north-east Ireland, Mr. J. P. T. Burchell described the geological conditions under which specimens he exhibited were collected. Mr. J. Reid Moir reviewed the typological evidence of the exhibits, showing that the line of evolution from ancestral eolithic forms and the technical methods of flaking used were identical with those in the lower palæolithic industries of widely separated regions. Dr. Muir Evans exhibited a fine bone harpoon from the North Sea bed, deeply peat-stained and similar to the two examples from Holderness now in the British Museum. The specimen came from a large mass of 'moorlog' dredged up between the Leman and Ower sandbanks, about thirty-five miles east of Happisburgh lightship, by the trawler Colinda. Mr. M. C. Burkitt accepted the harpoon as clearly of Maglemose type. The specimen has been presented to the Norwich Museum.

\section{Fungicide for Oat Seed}

ExpERIMENTs carried out at the North of Scotland College of Agriculture, at Craibstone, in 1931, clearly demonstrate the value of dressing oat seed with 'Ceresan', for on an average the yield of grain was $6 \mathrm{cwt}$. and the yield of straw 8 cwt. per acre higher on the treated than on the untreated plots. Ceresan is a mercuric compound in the form of a dry powder, which, when mixed with the seed, kills any fungi that may be adhering to the grain. Thorough mixing is essential if the treatment is to be successful, and special machines are now on the market for the purpose. An old churn, however, has been used at Craibstone with very satisfactory results. Mixing on the floor with a shovel is not recommended, partly on account of the difficulty of obtaining a sufficiently thorough mixing by this means, and partly because of the poisonous nature of the compound and the consequent risk of danger to live stock. Care is therefore needed in handling the powder, and if large quantities are being used, it is advisable for workmen to cover their noses and mouths as a precautionary measure. Five ounces are required for every hundredweight of seed, the cost, exclusive of labour, working out at less than one shilling per acre. Although a good stand of oats, such as was obtained on the plots where the seed had been treated, is eminently desirable, too thick a crop is liable to suffer from lodging, and it seems possible that a saving of seed could be effected if Ceresan treatment were carried out. This and other points of importance, such as the influence of weather conditions at harvest on the effectiveness of the treatment, etc., will be investigated in the experiments which are being continued at Craibstone in the present season.

\section{Submerged Canyon of the Hudson River}

Scrence Service has issued a summary of a recent United States broadcast talk on hydrographic matters, by Lieut.-Comm. R. R. Lukens, of the United States 